\title{
The Optimization of Protection Policy for Indonesian Women Migrant Workers from the South Central Timor Regency
}

\author{
(1) Dominggus J. O. Banunaek*; (2) Basri K; (3) Kotan Y. Stevanus, \\ Master's Program in Administrative Science, Postgraduate Program, Universitas Nusa Cendana, Indonesia \\ Corresponding email: hansbanunaek3@gmail.com
}

\begin{abstract}
This research aims at (1) Analyzing how optimal the implementation of protection policies for Indonesian Women Workers is, and (2) Exploring what practical and juridical social barriers are related to the policy of protection of Indonesian Women Workers. This study employed a qualitative approach using a case study method. This research was conducted in the Tubuhue village of West Amanuban District, South Central Timor Regency, East Nusa Tenggara. This study used primary data and secondary data. The data were collected through interview, documentation as well as observation techniques. The data were analyzed using thematic analysis, in which all interview results were grouped using a thematic matrix to facilitate the researchers in describing the results of research in answering each research question.

The research results show that the facts regarding the protection of TKI (migrant workers)/TKW (women migrant workers) abroad indicate that the legal protection for migrant workers during the pre-placement, placement and the post-placement process is still far from perfect or has not been implemented optimally. Nevertheless, there have been several efforts to help optimize protection policies through social approaches undertaken by the government and the people of South Central Timor Regency in East Nusa Tenggara.
\end{abstract}

Keywords: Policy, Labor, Women, Policy Optimization

DOI: $10.7176 / \mathrm{DCS} / 9-12-09$

Publication date: December $31^{\text {st }} 2019$

\section{BACKGROUND}

The problems of Indonesian migrant workers or Tenaga Kerja Indonesia (abbreviated as TKI) have recently been highlighted by various parties. In 2018, there were 4,696 reported cases related to TKI problems.

Table 1.The Number of complaints by problem type in 2017-2018

\begin{tabular}{|c|c|c|c|}
\hline No & Type of Problem & 2017 & 2018 \\
\hline 1 & TKI wishing to return home & 428 & 332 \\
\hline 2 & Unpaid salary & 390 & 228 \\
\hline 3 & TKI failing to depart (from Indonesia) & 248 & 226 \\
\hline 4 & Illness & 246 & 176 \\
\hline 5 & Layoffs before the work agreement period ends & 227 & 56 \\
\hline 6 & Losing contact/ communication with TKIs & 163 & 107 \\
\hline 7 & Undocumented TKIs & 373 & 441 \\
\hline 8 & $\begin{array}{l}\text { The unconformity between TKIs' work and } \\
\text { employment contract }\end{array}$ & 137 & 59 \\
\hline 9 & Employers doing violence to TKIs & 66 & 32 \\
\hline 10 & Salary deductions exceeding the regulations & 142 & 65 \\
\hline 11 & TKIs having accidents & 50 & 15 \\
\hline 12 & Illegal recruitments of prospective TKI & 59 & 27 \\
\hline 13 & TKIs being in custody/detention process & 57 & 59 \\
\hline 14 & $\begin{array}{l}\text { Passport or other document detention by the } \\
\text { PPTKIS (Private Indonesian Manpower Supplier } \\
\text { Company) }\end{array}$ & 70 & 43 \\
\hline 15 & $\begin{array}{l}\text { TKIs not having fares for going back home (to } \\
\text { Indonesia) }\end{array}$ & 48 & 23 \\
\hline 16 & Fraudulent job opportunities & 39 & 19 \\
\hline 17 & Document forgery & 26 & 10 \\
\hline 18 & Inharmony between TKIs and the employer & 24 & 11 \\
\hline 19 & TKIs running away from the employer & 14 & 2 \\
\hline 20 & Sexual harassment & 10 & 4 \\
\hline 21 & Others & 1.658 & 2.761 \\
\hline & TOTAL & 4.475 & 4.696 \\
\hline
\end{tabular}

Source: http://www.bnp2tki.go.id/uploads/data 
Table 2. The Number of Cases based on 2017-2018 TKI Complaints Scheme

\begin{tabular}{llcc}
\hline No & \multicolumn{1}{c}{ Complaint scheme } & $\mathbf{2 0 1 7}$ & $\mathbf{2 0 1 8}$ \\
\hline 1 & Placement Period & 3,747 & 4,087 \\
2 & Pre-placement & 478 & 360 \\
3 & Full Placement & 250 & 249 \\
\hline \multicolumn{2}{r}{ TOTAL } & 4,475 & 4.696 \\
\hline
\end{tabular}

Source: http://www.bnp2tki.go.id/uploads/data

Tables 1 and 2 show that there was a 5\% increase in the number of cases in 2018 , in which $87 \%$ of the cases occurred during the placement of migrant workers. In addition, the news about the migrant workers has been a fervent discussion among state officials, politicians, NGOs and it frequently becomes a discourse in the conversation. Some of the cases are Nirmala Bonet, a TKI from NTT (East Nusa Tenggara) who was abused in Malaysia in 2004, and Sumiati, a TKI from NTB (West Nusa Tenggara) who was tortured in Saudi Arabia in 2010; there are also the executions of Tuti Trusilawati in Saudi Arabia (Merdeka.com, December 2nd, 2018), and the case of Adelina Sau from (South Central Timor) that are still fervently discussed along with various other cases. NTT province is one of the provinces contributing migrant workers from Indonesia. In 2018, there were 2,077 people of whom $88.40 \%$ were female migrant workers from 22 districts and cities. A number of cases are related to migrant workers from NTT, and this is a serious problem in the province. South Central Timor Regency is one of the districts contributing $15 \%$ or as many as 317 migrant workers from NTT province in 2017-2018; accordingly, a good few of reported cases were experienced by TKI from South Central Timor Regency.

Based on the data of the South Central Timor Regency Manpower Office training and employment in 2017 and 2018, there were 56 cases of migrant workers with two types of problems: (1) ill and deported migrant workers, and (2) deceased migrant workers. Even with the existence of the Policy on the Protection of Women from Violence (Regional regulation No. 9 of 2015) and Regional regulation No. 5 of 2015 concerning Prevention and Management of Trafficking Victims in South Central Timor District, the data indicates that $18 \%$ of South Central Timor migrant workers experienced problems of which 36 were cases related to female workers,

Illness, work accidents, depression, pregnancy at work, and unpaid salary were the reasons leading to discharged or deceased migrant workers. As much as $87.5 \%$ of the migrant workers registered by the South Central Timor employment agency experienced the problem of departing through illegal or non-procedural channels.

Table 3. The Recapitulation of TKIs Having Problems by Departure Category for 2017-2018

\begin{tabular}{ccccc}
\hline \multirow{2}{*}{ No } & \multirow{2}{*}{ Type of problem } & Tahun & Legal & Illegal \\
\cline { 3 - 5 } & & & & 12 \\
& Being ill / deported & 2018 & 4 & 17 \\
& & 2017 & & 7 \\
& \multirow{2}{*}{2} & 2018 & 3 & 13 \\
& & 2017 & $\mathbf{7}$ & $\mathbf{4 9}$ \\
\hline
\end{tabular}

Source: The Department of Manpower Training and Placement of Workers of South Central Timor Regency

Related to labor cases, the regional and village government facilitate some of the funding for the return of problematic TKI candidates from the transit area, assist the administration of the return or collecting the bodies sent back to the Region (Deportation), and if needed, prepare documents for proving that the deceased is a citizen of the village concerned. In relation to policies, the regions have issued policies on supervision of Trafficking in Persons (Regent regulation no. 30 of 2018) and established a task force team to monitor and report any indications of recruitment, migrant-workers sending, or criminal acts related to trafficking in persons (Regent regulation no. 40 of 2018).

This study aimed to analyze the optimization of protection policies implementation for Indonesian women workers; it also explores the practical and juridical social barriers concerning the policy of protection of Indonesian women workers. This study is expected to make a theoretical contribution to the protection of Indonesian workers, especially women leaving and returning from abroad in preparing themselves through the provision of knowledge and skills; it is also expected to serve as a foundation for further research. Furthermore, it can be an input for the Regional Government in formulating government policies and programs through planning and developing human resources to improve the skills of workers whilst and after they work. 


\section{Protection of Women Workers}

\section{LITERATURE REVIEW}

Work protection aimed at providing a guarantee for the continuity of the employment relationship system without involving 'the strong putting pressure on the weak'. For this reason, the employer is obliged to implement the protection provisions according to the applicable laws and regulations. The scope of protection for workers/laborers according to Law No. 13 of 2003, which includes:

1. Protection of the basic rights of workers/laborers to negotiate with employers.

2. Safety and work protection.

3. Special protection for women/children and disabled workers

4. Protection on wages, welfare, workforce social security (Jayantari, 2013).

Asyhadie (2007) stated that the labor protection is divided into 3 (three) types:

\section{Economic protection}

It is the protection of workers in the form of adequate income; this includes the workers' undeliberate inability to work. As the organizer of the social security program, it is the State's responsibility and obligation to provide social and economic protection to the community. Conforming to the state's financial capacity, like many developing countries, Indonesia develops social security programs based on funded social security, which is funded by participants and still limited to the working community in the formal sector.

Workers' social security is a protection for workers in the form of financial compensation in exchange for a portion of lost or reduced income and services as a result of events or conditions experienced by workers in the form of work accidents, illness, pregnancy, childbirth, old age and death (Labor Social Security Act, No.3 of 1992, Article 10 .

\section{Social Protection}

It includes labor protection in the form of work health insurance, freedom of association and protection of the right to join an organization as the provisions regarding occupational health are related to social, that is, regulations to impose limitations on the power of employers to treat the workers/laborers as they please without regard to prevailing norms, by not seeing workers/laborers as God's creatures who have human rights.

As it intends to hold "restrictions", the provisions of social protection in Law No. 13 of 2003 Chapter X Article 68 and so on, are "forcing", not regulating. As a result, the legislators consider it necessary to explain that the provisions relating to social protection are "general law" (Publiek-rechtelijk) with criminal sanctions. Thus, it is clear that occupational health protection intends to protect workers/laborers from the occurrence/conditions of employment relationships detrimental to their health and decency when the workers do the work. The emphasis in "employment relationship" indicates that all workers not having an employment relationship with employers do not get social protection as stipulated in Chapter X of Law No. 13 of 2003.

\section{Technical Protection}

It includes the protection of workers in the form of security and work safety so that they are safe from hazards caused by working tools or materials. In contrast to other work protections, which are generally determined for the benefit of workers/laborers, work safety does not only provide protection to workers/laborers, but also to employers and the government.

In Indonesia, the legally-regulated protection specifically for women workers includes four factors: protection of working hours, protective regulations, collective protection, and non-discriminatory protection. The description of each type of protection is as follows:

\section{a) Protective Regulations}

Women workers or laborers are groups having certain characteristics that need to be paid attention to; therefore, in some cases, there are special regulations concerning the protection of women workers/laborers including prohibitions on night-shift/work, work involving health hazards, and regulations related to women decency. The protective regulations include: (1) menstruation leave; (2) maternity/miscarriage leave; (3) opportunities for breastfeeding during working hours; (4) elimination of differences in the treatment of female workers/laborers; (5) social security and wages; (6) rest/annual leave arrangements.

Increased protection for female workers can also be seen through several provisions eliminating the differences in the treatment of female workers: (1) Law No.80 of 1957 concerning the ratification of ILO (International Labor Organization) Convention No.100 of 1954 concerning equal pay between men and women for works of equal value; (2) Government Regulation No.8 of 1981 concerning wage protection asserting the sanctions for violations of the stipulated conditions; (3) Regulation of the Minister of Manpower Number per.04/MEN/1989 concerning the prohibition of layoffs for women working due to pregnancy or childbirth. This Ministerial Regulation states that employers must not reduce the rights of women workers due to pregnancy and physical condition causing their inability to do a certain types of work. 


\section{b) Collective Protection}

It is in Law No.13 of 2013 Article 176. The implementation of supervision consists of a series of activities including (1) Preparation of work plans; (2) Inspection in the company or workplace; (3) Preventive and repressive measures; (4) Reporting on inspection results.

\section{c) Non-Discriminative Protection}

With the issuance of Law No. 7 of 1984 concerning the ratification of the UN Convention on the elimination of all forms of discrimination against women, the protection of women workers/laborers from discriminatory behavior is affirmed.

\section{Legal Constraints in the Policy for Women Migrant Workers Protection in South Central Timor Regency}

The implementation of legal protection for women workers is constrained by the existence of worker-employer agreement which sometimes deviates from the applicable regulations, the absence of sanctions from the legislation for violations, and the factor coming from the worker when she does not exercise her rights due to economic reasons. To make the policy effective, the state must elaborate and endeavor to include it in the formulation of state law as well as enforce it by bringing its users to court. Nevertheless, many women are still unaware of their protected rights and that the rights affect their lives.

ICEDAW (International Convention on Elimination of All Forms of Discrimination against Women) ordered all countries in the world not to discriminate against women. In this convention, it is determined that discrimination against women is a differential treatment based on gender which: (1) intentionally or unintentionally harms women; (2) prevents society as a whole from recognizing women's rights both at their homeland and abroad; or (3) prevents women from using their basic human rights and freedoms.

\section{Thinking Framework}

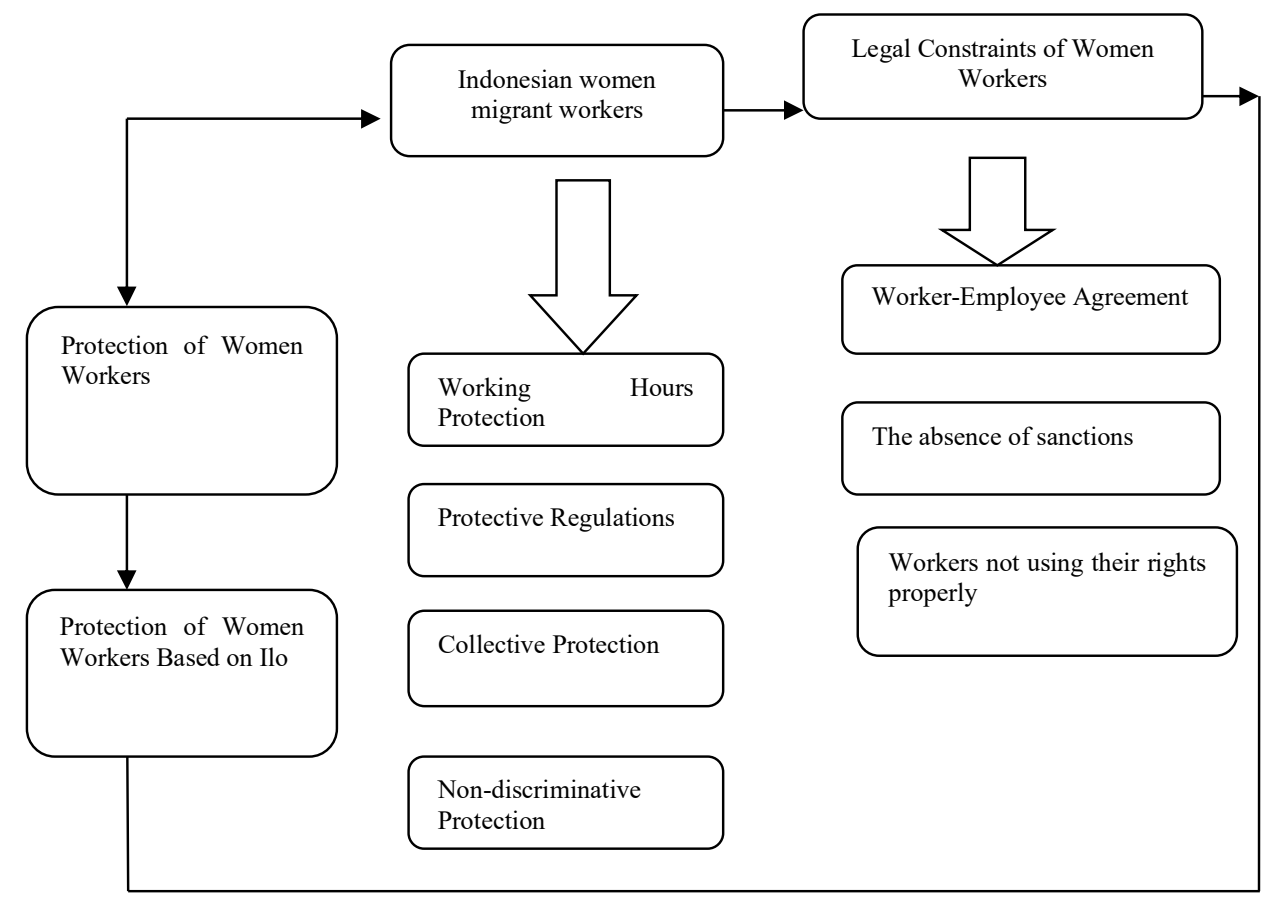

RESEARCH METHODS

This research employed a qualitative approach with a case study method. This research was conducted in the Tubuhue village of West Amanuban District, South Central Timor Regency, East Nusa Tenggara. The type of data used in this study was primary and secondary data. The data were collected through interviews, documentation and observation techniques. Data collected from informants were analyzed using thematic analysis, in which all interview results were grouped using a thematic matrix to facilitate the researchers in describing the results and answering each research question. Data tabulation was performed to describe each secondary data obtained from each source. 


\section{RESEARCH RESULTS AND DISCUSSION}

\section{The Forms of Protection for Indonesian women migrant workers from South Central Timor Regency, East Nusa Tenggara Province}

In this study, the in-depth discussion is more directed at efforts to provide protection for Indonesian Woman Migrant Workers (Tenaga Kerja Wanita or TKW); it is based on the data of Indonesian migrant workers placement in 2014-2018. Most of the migrant workers sent to work abroad from the province of East Nusa Tenggara were female; moreover, they is a labor force very vulnerable to crime.

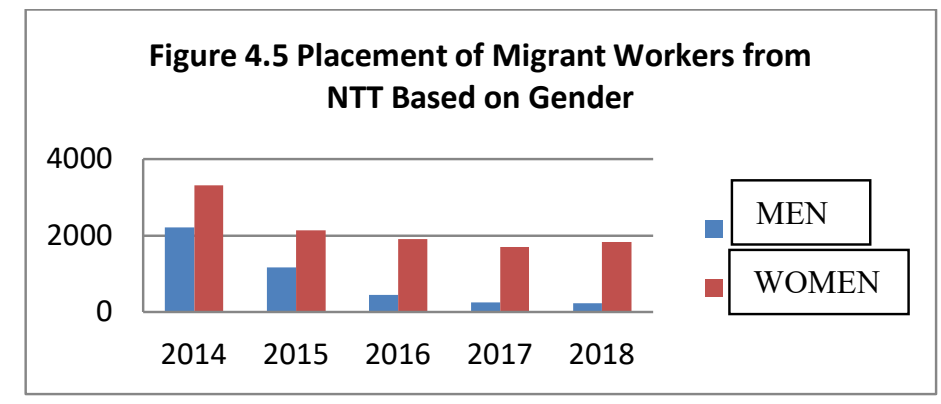

Source: BNP2TKI Placement and Protection Data of 2018

The efforts to provide protection for women migrant workers abroad are as follow:

1. Protection of women migrant workers in the home country;

2. Protection of women migrant workers in the destination country;

3. Protection of women migrant workers post-placement;

4. Protection of undocumented women migrant workers.

\section{Protection of women migrant workers in the home country}

There are several problems encountered by migrant workers in the home country, especially during pre-placement in which some of the cases are not covered in the protection article or in the article concerning the rights of migrant workers; for instance, the case in which they cannot contact their family in the homeland, deprivation of liberty when they are sheltered in their country, and when they are not given the freedom to make choices regarding employment of talent and ability. In addition, they have limited access to advocacy and social security networks, they are not allowed to prepare their own food or even to carry out religious ceremonies/worship; aside from that, they also experience problems related to family life, viz. being exiled and cheating husband or wife, divorce, homesickness, family relationship problems, etc. All of the aforementioned problems are not accommodated in Law No. 39 of 2004 concerning the Penempatan dan Perlindungan Tenaga Kerja Indonesia di Luar Negeri (UUPPTKLN) - Placement and Protection of Indonesian Migrant Workers Abroad, specifically regulating the rights and obligations of Indonesian workers. Therefore, the protection system for migrant workers while still in the home country will be a benchmark for optimizing protection abroad, and should be the start of the next protection system conceptualization; it does not come to a logical extreme: even in their own country, migrant workers have not received optimal protection, so it will get even worse after they have arrived in the destination country; there must be more solid protection, both in terms of legal and social protection.

Regarding the issue of implementing placement regulations while migrant workers are in a shelter, there is no explicit editorial related to the obligation for the implementing agency to protect migrant workers as stated in article 70, which states as follows: "That the person having the authority place private Indonesian Workers can accommodate shelter for prospective Indonesian Workers before departure, of which the duration is based on the position and/or type of work to carry out in the destination country, in which the placement of Indonesian Workers is in a natural and humane manner". This shows that the process of implementing the placement of migrant workers during the shelter period or prior to departure is prone to intimidation and discrimination because the article does not clearly regulate the responsibility for implementation for protection; thus, it does not reflect the selectivity of protection forms during the shelter needed so as not to complicate labor migrants. More ironically, this has created a loose system to suppress the sending of illegal labor that can harm migrant workers, as well as to defame the nation and state. 
A great deal of less competent and illegal migrant workers was sent due to these loose protection and supervision systems, which almost all lead to exploitation and criminal acts of trafficking in persons. This was clearly seen in the recruitment of migrant workers in the province of East Nusa Tenggara. In 2016, the NTT Province Placement and Protection Service for Migrant Workers (BP3TKI) recorded as many as 400 cases of sending migrant workers leading to acts of human trafficking; this number began to decline in 2017 as there were 137 cases of sending illegal migrant workers indicated in the act of action human trafficking. This indicates that the regulation of supervision and protection for prospective migrant workers when they were still in the country was not running optimally.

The high number of cases involving Indonesian women migrant workers proves that a review of policies made by the government both at national and regional levels is needed. Additionally, supervision needs to be increased since the recruitment period (pre-placement), placement and post-placement. In response to this, the Indonesian government issued Law No. 18 of 2017 concerning the Protection of Indonesian Migrant Workers. The issuance of Law No.18 of 2017 is based on the consideration that the provisions governing the placement and protection of Indonesian workers abroad contained in Law No.39 of 2004 concerning the Placement and Protection of Indonesian workers abroad have not been able to meet the needs of Protection of Indonesian migrant workers/TKI. Furthermore, Law No.39 of 2004 has not regulated the division of tasks and authority between the Central Government, regional and Private Governments proportionally. In this law, the role of TKI Protection is in the hands of the central and regional governments, starting from before, during, and after work.

In addition to the issuance of Law No. 18 of 2017 Regarding the Protection of Indonesian Migrant Workers, the provincial government of East Nusa Tenggara has issued the Decree of the Governor of East Nusa Tenggara No.358/KEP/HK/2018 concerning the Termination of the Appointment of Inter-Regional Worker Candidates from East Nusa Tenggara Province to Outside of East Nusa Tenggara Province. This Governor's Decree was issued due to the increasing number of cases of sending illegal TKIs and the rampant cases of human trafficking in the province of East Nusa Tenggara. The decree still allows the appointment of prospective migrant workers from East Nusa Tenggara province provided that the prospective workers must have competence proved by having graduation certificates of education and training. This shows that each Private Indonesian Manpower Supplier Company (Pelaksana Penempatan Tenaga Kerja Indonesia Swasta or PPTKIS) or local government must provide a Job Training Center (Balai Pelatihan Kerja or BLK) in East Nusa Tenggara province so that the education and training program is implemented in the local area.

In addition to legal protection, social protection is also needed for migrant workers during the pre-departure period. This protection focuses more on technical matters, especially social protection for Indonesian Women Workers. The social protection system can be carried out as follows:

a) Providing a supply of reproductive health issues and mental health services including contraceptive services and HIV/AIDS intervention programs.

b) Providing orientation programs for Indonesian Workers' families such as management of remittances, reorganization of household responsibilities and domestic work, a strong foundation in marital life, communication with migrant workers.

c) Conducting public awareness campaigns by taking into account vulnerability points, and recommended types of works: jobs in the destination country that are promoted by Indonesia for women workers and jobs that can reduce the problem of undocumented migrant workers at the grassroots level.

d) Promoting the use of electronic communication for sharing various information to the prospective migrant workers and for communicating with families in their hometown.

e) Providing recruitment services for migrant workers who wish to migrate again.

Social approaches to the protection of migrant workers by the government have commenced in the South Central Timor Regency, East Nusa Tenggara Province; for instance, the construction of secure migration information house program in the Body of West Amanuban subdistrict and in Toianas Village, Toianas Subdistrict, South Central Timor Regency, in which the two villages have been designated as Productive Migrant Villages (desmigrative). The safe migration information house is expected to help the local government to record every prospective migrant worker who wants to work or has been working outside the area, as well as to provide information on the procedures for safe migration. Some other social programs for the protection of migrant workers are also carried out by related agencies in the South Central Timor Regency, for example, the TKI Family Development Program (Program Bina Keluarga TKI or BKTKI) conducted by the Office of Women's Empowerment and Child Protection (Pemberdayaan Perempuan dan Perlindungan Anak or P3A); the programs implemented include: a) Socialization of the conditions for becoming a migrant worker; b) Parenting life program; 
c) Formation of task forces in each village to monitor TKIs/TKWs who arrive to and depart from the village, also to monitor the 'brokers' coming to recruit non-procedural TKIs/TKWs in the village.

Apart from the programs implemented by the government for the protection of migrant workers, especially the pre-placement, other protection programs are also carried out by the Church through the 'pastor voice' and also the sermons in their respective congregations on how to migrate safely and the procedures that should be followed by prospective TKIs/TKWs; this is a form of socialization for the protection of TKIs/TKWs achieved through preventing the village community from sending illegal TKIs/TKWs indicated as human trafficking. In addition, the families of migrant workers are given assistance to create a sense of security. NGOs in South Central Timor regency also provide other protections due to the high number of criminal cases against migrant workers.

\section{Protection of Indonesian TKWs in the Destination Country}

A very important issue regarding the protection of migrant workers after arriving in the destination country is work placements in accordance with their talents and desires. Accordingly, before departure, must have a placement cooperation agreement document, a request for migrant workers (job order/demand letter) on behalf of the PPTKIS concerned, a work agreement, and a placement agreement for migrant workers, and others required by the destination country. There are several other obligations that must be carried out by PPTKIS with regard to the completeness of documentation of Indonesian migrant workers in the process of overseas departure, i.e. PPTKIS is obliged to legalize the placement cooperation agreement with the RI representative in the local country and be registered with the Directorate General. The placement cooperation agreement shall at least contain the rights and obligations and responsibilities of PPTKIS and users or business partners in the context of the placement and protection of Indonesian workers.

In the destination country, PPTKIS must place labor migrants according to the work agreement, and the agreement must contain at least: (1) Name and address of the user; (2) Type and description of work; (3) Conditions of work which include: hours of work, wages, and methods of payment, overtime pay, leave and rest periods, and social security. PPTKIS is prohibited from changing the work agreement signed by the parties. The work agreement is valid for 2 (two) years and can be extended for a maximum period of 2 (two) years.

Legal protection relating to work agreements abroad, or employment relationship held by Indonesian workers abroad is included in the aspect of international civil law (Hukum Perdata Internasional or HPI), thus dealing with which legal issues are competent to adjudicate if a dispute occurs. In determining such a law, there is a valid principle, namely the principle of "lex loci executionis" or "the principle of lex loci solutionis"; it states that the law of an applicable employment agreement is the law of the country where the employment agreement is implemented. In the case of migrant workers abroad, the applicable principle is "lex loci delicti commisi", and thus, labor law and Indonesian law cannot provide protection for migrant workers concerning the implementation of work agreements abroad. To cover this weakness, the Government of Indonesia makes the bilateral agreements with migrant workers host countries as recommended by the ILO.

Furthermore, as long as migrant workers are in the country where they are placed, the PPTKIS is obliged to individually and jointly protect and defend the rights and interests of migrant workers abroad; this implementing agency must also appoint or cooperate with the TKI Protection Institute consisting of legal consultants and/or insurance institutions in the country of placement of migrant workers in accordance with the provisions in force in the country concerned. This cooperation must be included in the agreement, which at least: contains provisions regarding the obligations of Legal Consultants and/or Insurance Institutions to resolve disputes between TKIs with users or with third parties, provides consultation or legal assistance for migrant workers who have problems, arranges settlement of payments for unpaid migrant workers' salaries, handles the rights of migrant workers in the termination of employment, handles the completion of security for the risk of work accidents or deaths experienced by migrant workers related to work, and resolves the non-material loss problems of migrant workers. Furthermore, the representatives of the Republic of Indonesia collaborate with the TKI Protection Institute to collect data and monitor the existence of TKI to help provide protection and defense for migrant workers in the accreditation area. In addition, PPTKIS is required to assist and care for migrant workers who experience illness, accident, or death during their work placement abroad.

\section{TKW Post Placement Protection}

In reviewing the history of the law, the protection of migrant workers, including Indonesian migrant workers overseas after placement, is regulated by Kepmenakertrans No.104 A/MEN/2002. Article 61 of the Minister of Manpower and Transmigration requires PPTKIS to handle returning migrant workers with problems or expired work agreements, leave, and departure for returning back to the destination country after the termination of the work agreement or leave. Law No. 39 of 2004 concerning the Placement and Protection of Overseas Indonesian Workers article 77 paragraph (2) states that the protection referred to in paragraph (1) is implemented starting from the pre-placement, placement period, and after placement. This implies that PPTKIS is required to collaborate with 
business partners and RI representatives abroad to handle returning migrant workers to the Indonesian airport, also when their work agreement has ended and is not extended.

In addition, the implementing agency has to deal with migrant workers who have problems, illness or those who die during the work agreement, thus they cannot fulfill the work agreement. The next process, PPTKIS must notify the return schedule of Indonesian Migrant Workers to RI representatives in the local country and the Directorate General of the Ministry of Manpower and Transmigration no later than 7 (seven) days before the return date; PPTKIS is responsible for helping with the problems, and handling or bearing the care costs of sick migrant workers or those who have deceased.

The after-placement protection for women migrant workers is also implemented after they return to their respective villages or regions. The rise of illegal sending of labor requires all parties to work together in dealing with the problem, for instance, the Department of Manpower and Transmigration in the south Central Timor district through the ministry program creates groups of former TKI/TKW to attend training and develop entrepreneurship programs. They are grouped based on their talents: weaving, local food processing, agriculture and animal husbandry. The training and entrepreneurship development is expected to create new jobs for people in the village (see Figure: Appendix 2 Photos/figures 1-4) although there are only a few people who are successful in their business.

\section{Protection of undocumented TKW}

Although efforts have been made to increase the world attention on international migration and migrant workers, there has not been any real impact on the protection of migrant workers' rights, especially female domestic workers and those who do not have documents; as of today, they are still nationally and internationally excluded from the effective legal system in any country.

The law enforcement approach to migration arrangements in destination countries places undocumented migrant workers in a disadvantageous position; it is contrary to the high demand for migrant workers as they must bear the consequences of being targeted by unfair treatment as criminals and labeled as "illegal". Proper steps are needed to address the inconsistency of the protection framework on the one hand, and the high market demand for undocumented migrant workers on the other. Economically, there is an urgent need to recognize and accurately measure the high market demand for undocumented migrant workers and domestic workers in rich industrial countries.

Considering the frequent fraudulent-cases often experienced by migrant workers conducted by brokers such as a fabricated promise of giving a passport before entering Malaysia, a large number of migrant workers become illegal bearing various consequences. Many Indonesian citizens enter Malaysia illegally, clandestinely, and without documents. Based on these facts, the International Convention on the Protection of the Right of All Migrant Workers and Members of Their Families does not discriminate against the rights of migrant workers, whether it is documented or undocumented; additionally, the principles of universality of human rights guarantee equal protection for undocumented migrant workers and domestic migrant workers.

Efforts have been made for the migrant workers abroad to obtain protection from various parties concerned, especially from the government. It is confirmed by the increased provision of information to the public and the issuance of legislative instruments that directly or indirectly have suppressed cases of human rights violations against Indonesian migrant workers. Although there has been an increase in efforts to provide information to prospective workers vulnerable to all forms of violations depriving them of their rights, there are still many victims who do not understand the services that they should receive and deserve compared to the treatment of the local government that considers them as criminals, and illegal or undocumented migrants.

The training of prospective migrant workers prior to departure is considered insufficient to provide information about their rights as migrant workers, various problems that may occur later at work, how to protect themselves, and where they can get assistance. The efforts are made not only by the government but also through cooperation with Non-Governmental Organizations concerning about the fate of Indonesian Workers abroad, that include the following activities:

1. Forum 182 Batam in collaboration with various NGOs published a small pocketbook entitled "Information Guide to Fight the Practice of Human Trafficking" which was disseminated to those who had received help, so they can share it with their colleagues so as not to suffer the same fate as them. However, if somehow, they encounter a vulnerable situation, rescue measures will be taken as necessary.

2. ICMC in collaboration with the Ministry of Women's Empowerment, ACILS, and USAID has published and distributed free comics entitled "The Adventure of Wening and Friends. There is Always a Way Home" to groups of people who are considered vulnerable to trafficking in persons, such as school children, adolescent girls in rural areas, and others. The dissemination of this comic 
works in collaboration with a network of NGOs concerned with migrant workers throughout Indonesia.

3. IRGSC, Wahana Visi Indonesia (WVI), and the Evangelical Christian Church of Timor (GMIT) in collaboration with the Office of Women's Empowerment and Child Protection (P3A) of South Central Timor Regency, East Nusa Tenggara Province, provided socialization and issued public service announcements via radio and banners campaigning against human trafficking. The provision of information to vulnerable groups of people, also to the target group, is also conducted through officers tasked with dealing with victims of trafficking such as police officers, shelter officers, victim assistance officers, local governments and related agencies through the delivery of leaflets and posters issued by the Coordinating Ministry for People's Welfare disseminated to the offices and the Regional Government every time conducting socialization, advocacy, and monitoring to the regions.

4. Socializing and advocating international provisions regarding the treatment that must be given to victims of trafficking in relation to their rights such as not treating them as criminals, concealing the identity of victims, providing protection from threats of traffickers, providing health recovery assistance and/or trauma counseling and other rights; moreover, the socialization is delivered to the police and the mass media so when they write reports, the identity of the victim is protected.

5. The Government of the Republic of Indonesia in collaboration with the Focal Point of the Ministry of Women's Empowerment in collaboration with the ICMC in 2004 prepared Standard Operating Procedures (SOPs) for Returning Victims of Trafficking in Persons; in addition, education and training modules are compiled for program managers from Indonesian representatives abroad to the relevant institutions in the country, including NGOs and community organizations concerned. This SOP and various pre-existing guidelines will continue to be promoted by prospective migrant workers and the public so that they can know their rights. Thus, the authorities can act accordingly in dealing with human trafficking victims. The efforts will also be made by the Government of neighboring countries and other destination countries to provide protection to victims of trafficking in cooperation with representatives of the Republic of Indonesia in the country concerned.

\subsection{The Constraints in Implementing Protection Policies on Women Workers from South Central Timor Regency, East Nusa Tenggara Province}

East Nusa Tenggara Province is an archipelago having large islands, such as Sumba, Flores, Alor, Timor, and small islands as well. The application of protection policies for TKI/TKW from South Timor Tengah Regency, East Nusa Tenggara Province undergo the following constraints:

\section{Poverty}

Economically, South Central Timor Regency of East Nusa Tenggara Province is a very poor district; according to a report from the Central Statistics Agency for South Central Timor Regency in 2015, the average income per capita of South Central Timor district residents was IDR 13,215 / day or IDR 396,466 / month. These are the recorded figures, but in reality, there are those do not earn that much. Poverty is a major factor driving people to do anything to deal with deficiencies. To understand how this universal issue acts as a cause, it is important to examine three specific aspects of poverty: the supply side, the demand side, and the interaction between these two forces; the supply side is influenced by individuals' poverty factors (limited facilities and access to the necessities of life), while the demand side refers to commercial industries or activities relying on poverty as commodities (individuals traded illegally) aiming at maintaining profits.

Based on institutions or organizations' majority view regarding the matter, the main factors and root causes of crime against TKI/TKW are influenced by the supply side and the demand side caused by poverty. Poverty drove hundreds of residents of South Central Timor Regency to domestically and internationally migrate as a way to have a better life for themselves and their families.

The rise of human trafficking and the sending of illegal TKI/TKW from East Nusa Tenggara (NTT) were allegedly due to poverty occurred the eastern part of Indonesia. The Migrant Care Executive Director, Anis Hidayah, stated that it is for this reason that the workers are easy targets as victims of offenses against women. Human trafficking and other cases affecting migrant workers from East Nusa Tenggara Province is a consequence of poverty and lack of access to welfare. Inequality and poverty raise problems for women's rights in the province of East Nusa Tenggara; it has also become one of the constraints of implementing protection for TKI/TKW. It is required that they improve their economic conditions. In this state, they are increasingly depressed and easily influenced by the 
risk of crime. Poverty is a major social problem in the NTT province, particularly in the district of South Central Timor. The effect of poverty leads to various social impacts. There is an alarming fact that the consequences of poverty place NTT women at a high risk of being a victim of crime, intimidation, and exploitation of human trafficking practices.

\section{Low Level of Education}

The high cases of human trafficking and sending illegal TKI/TKW in NTT are not only due to poverty or economic factors but also to the low level of Human Resources (HR) development in education. Most of NTT residents are illegally recruited as TKW-TKI since they do not understand the dangers and risks. It is led by the low level of education, viz. an elementary school graduate or even not going to school at all. It is easy to trick and deceive them because of their lack of knowledge; thus, they are 'easy targets' of human trafficking. In this context, it appears that underdeveloped economic conditions and minimal human resources make NTT, specifically South Timor Tengah regency, a "Human Emergency" province, in which the people are easily tricked into getting good jobs and being rewarded with high salaries; this situation creates 'a wetland' for brokers.

Case studies were conducted on 9 former migrant workers from South Central Timor Regency, East Nusa Tenggara Province; on average, they were graduated from elementary and junior high school and 3 of them were sent to work with forged documents when they were 17 years old, which is not a legal working age. They fell victims to perpetrators (brokers) in an organized plan of sending them abroad without providing any documents. In this case, they were facilitated with passport making in Jakarta and sent from NTT to Jakarta, and to Malaysia. Fortunately, they had a good employer so they could be sent home based on the proper procedures.

\section{Lack of Domestic Employment}

Unemployment is one of the constraints in the application of TKI/TKW protection policies from the South Central Timor Regency of East Nusa Tenggara Province. Various sources suggested that social problems greatly affect the complexity of crime in the province. Some victims are poor or vulnerable groups. As reported by the Indonesian Women's Union (Seruni), the high unemployment rate drives the exodus of migrant workers from NTT, and this is alarming. The unemployment rate reaches 88 thousand people. Seruni noted that there were 44 deceased victims from NTT due to cases of trafficking. Young women from NTT were easily recruited by labor service companies to become migrant workers. To some parents in NTT, poverty was the driving force in allowing their children to be recruited to work in overseas.

\section{Lack of Supervision and Involvement of Close-Related People}

The lack of supervision in the recruitment of prospective TKI/TKW is one of the constraints in implementing protection policies for TKI/TKW from the South Central Timor Regency of East Nusa Tenggara Province. This leads to frauds committed by field officers; if they are aware of the recruitment requirements, they will surely not recruit prospective TKI/TKW who are not in a legal working age or those who cannot speak Indonesian. In addition, the culture of "sirih pinang" (various items brought to someone as a mark of respect) in East Timor makes it easy for brokers to recruit people who have low level of education in rural areas; the brokers' "uang sirih pinang" (sirih pinang money) can gain the community's sympathy, especially parents. In doing so, the parents will give permission to take their children to work outside the area.

The lack of protection for TKI/TKW causes a great number of human trafficking cases in the province of East Nusa Tenggara; this requires a solution and decisive action from law enforcement and security forces. In fact, the data shows that 10 members The East Nusa Tenggara Regional Police were allegedly involved in the human trafficking network.

\section{Limited Regional Budget}

When this research was conducted, it was found that one of the factors hindering the implementation of the protection policy for migrant workers in the district of South Central South East Nusa Tenggara Province was the issue of a limited budget. The government programs dealing with cases of prospective migrant workers cannot be implemented equally. To exemplify, the Community Assistance and Empowerment program can only be carried out in 2 of 32 sub-districts in the South Central Timor Regency. According to EM, a person responsible for the development of training and productivity in the Department of Manpower of South Central Timor Regency, there are many programs that have been designed by the ministry, but as soon as they reach the regions, not all programs can be implemented; also, the implementation is not evenly distributed because of the limited Regional Budget.

\section{CONCLUSION}

The facts regarding the protection of TKI/TKW abroad show that the legal protection for migrant workers during the process of pre-placement, placement, and post-placement is still far from perfect; it is safe to say that it has not 
been implemented optimally. However, there have been several efforts to help optimize protection policies through social approaches undertaken by the government and the people of South Central Timor Regency, East Nusa Tenggara.

\section{SUGGESTION}

We suggest that the efforts to protect Indonesian migrant workers should be increased, especially related to Indonesian female migrant workers, which can be done by:

a) Strengthening the protection policies through regulations on the education of women schools (vocations) of migrant workers; they should be more detailed, targeted, and effective, starting from facilitating recruitment / pre-placement to post work by building Vocational schools for women.

b) Capacity building and technical collaboration among relevant institutions such as PPTKIS, NGOs, BNP2TKI, Ministry of Manpower and Transmigration, Village Government networks, Religious Leaders, Customary Leaders, and the wider community.

\section{REFERENCES}

Asyhadie, Zaeni, 2007, Hukum Kerja: Hukum Ketenagakerjaan Bidang Hubungan Kerja, Jakarta: PT. Raja Grafindo Persada.

Dinas Ketenagakerjaan Kabupaten Timor Tengah Selatan, 2018. Bidang Pelatihan dan Penempatan Tenaga Kerja. ILO. 2013. ILO Evaluation Summaries. Promoting rights and opportunities for people with disabilities in employment through legislation (PROPEL) Midterm Evaluation.

ILO. 2007. Reader Kit: Overview of the ILO.

ILO. 2014. ILO Result: ILO Program in Indonesia 2014 Results.

International Convention on the Protection of The Rights of All Migrant Workers and Members of Their Families The 1990 United Nations International Convention on the Protection of Overseas Workers.

The 1966 Convention on Economic, Social and Cultural Rights.

ILO Convention No. 95 of 1949 concerning Wage Protection.

ILO Convention No. 97 of 1949 concerning Work Migration.

ILO Convention No. 181 of 1987 concerning Private Employment Agencies.

Decree of the Governor of East Nusa Tenggara Number. 358 / KEP / HK / 2018 concerning the Termination of the Appointment of Inter-Regional Worker Candidates from East Nusa Tenggara Province to Outside of East Nusa Tenggara Province.

Regional Regulation of East Nusa Tenggara Province No. 7 of 2016 concerning Services and Supervision of Indonesian Workers.

Regional Regulation of South Central Timor District No.5 of 2011 concerning Prevention and Handling of Victims of Trafficking in Persons in South Central Timor Regency

Law No.39 of 2004 concerning the Placement and Protection of Indonesian Workers Abroad.

Law No.39 of 1999 concerning Human Rights.

Law No.21 of 2007 concerning Prevention of Trafficking in Persons.

Law No.18 of 2017 concerning Protection of Migrant Workers. 